The Chittagong Univ. J. B. Sci., Vol. 6(1 \&2):175-185, 2011.

\title{
PREVALENCE OF MULTIDRUG RESISTANT STAPHYLOCOCCUS AUREUS ISOLATES IN CLINICAL SPECIMENS COLLECTED FROM LOCAL PATIENTS OF CHITTAGONG, BANGLADESH
}

\author{
S. U. KHAN ${ }^{1}$, M. N. MAHMUD ${ }^{1}$, M. A. CHOWDHURY ${ }^{2}$ AND M. A. HAKIM ${ }^{1 *}$ \\ ${ }^{1}$ Department of Microbiology, University of Chittagong, Chittagong-4331, Bangladesh \\ ${ }^{2}$ Chittagong Maa-O-Shishu General Hospital, Chittagong, Bangladesh
}

\begin{abstract}
To observe the prevalence of Staphylococcus aureus a total of 1078 blood, pus and miscellaneous samples (sputum, swab and body fluids) were collected among which 478 samples exhibited bacterial growth on agar medium. Out of growth positive 300 pus samples, 116(38.67\%) showed the growth of Gram positive cocci, of which $30(25.86 \%)$ were Staphylococcus aureus positive. In case of blood, the number of growth positive samples were 116(28.45\%), of which $33(12.12 \%)$ showed the presence of Gram positive cocci including 4 Staphylococcus aureus. Among the 62 growth positive miscellaneous samples, the number of Gram positive cocci and Staphylococcus aureus positive samples were $22(35.48 \%)$ and $4(18.18 \%)$, respectively. From the antibiogram of 38 Staphylococcus aureus isolates, 26 were found multidrug resistant, showing resistance against two or more of the antibiotics used namely ampicillin, cefradine, gentamicin and ciprofloxacin, whereas all the isolates were sensitive to vancomycin. The MIC and MBC of these antibiotics against different Staphylococcus aureus isolates were determined, which were found to range from $2 \mu \mathrm{g} / \mathrm{ml}$ to $8 \mu \mathrm{g} / \mathrm{ml}$ and $4 \mu \mathrm{g} / \mathrm{ml}$ to $16 \mu \mathrm{g} / \mathrm{ml}$, respectively, in case of vancomycin. The rate of resistance against ampicillin, cefradine, gentamicin and ciprofloxacin were $92.1 \%, 60 \%, 58.1 \%$ and $59.35 \%$, respectively.
\end{abstract}

Key words: Prevalence, Staphylococcus aureus, Multidrug resistance, MIC and $\mathrm{MBC}$

\section{INTRODUCTION}

Staphylococci are pathogens of man and other mammals (Todar 2008). It is the most frequently isolated bacterial pathogen in hospital-acquired infections and is a common cause of community-acquired infections, including endocarditis, osteomyelitis, septic arthritis, pneumonia and abscesses (Lowy 1998). S. aureus expresses a variety of extracellular proteins and polysaccharides, some of

*Corresponding author: hakimcu@yahoo.com 
which are correlated with virulence. Virulence results from the combined effect of many factors expressed during infection. Staphylococci are common causes of infections associated with indwelling medical devices. Some strains that infect hospitalized patients are resistant to most of the antibiotics used to treat infections(Foster 1994). S. aureus isolates from human sources confirms that they are normal inhabitants of skin and mucus membranes and are opportunistic pathogens (Mahmood et al. 2001). The emergence of pathogens with increased resistance to available antibacterial drug has historically been followed by development of "modern" antibiotics with improved activity for these resistant isolates (Polk 1999). Awareness of resistance pattern \& likelihood of emergent resistance are important in proper antibiotic selection (Fish et al. 1995). Antibiotics are one of the largest single groups of drugs prescribed. But due to the misuse of antibiotics and emergence of resistant strains the treatment of $S$. aureus infections has become a problem. This research work aimed at the determination of prevalence of Gram positive cocci $S$. aureus in various clinical samples as well as providing a specific guideline to the treatment of infection with this microorganism in local patients of Chittagong, Bangladesh with the presentation of total scenario of antibiotic resistance among the local isolates.

\section{MATERIALS AND METHODS}

\section{Samples}

This study was carried out from January 1, 2010 to June 30, 2010 on clinical isolates from indoor and outdoor patients in order to determine the prevalence of clinically significant Gram-positive cocci with special reference to S. aureus at Chattagram Maa-O-Shisu General Hospital, (CMOSH), Chittagong, Bangladesh. There were 1078 samples including blood, pus and miscellaneous samples (swab/sputum/ body fluid).

Among the total 1078 samples, pus samples were 549 (50.92\%), blood samples were $385(35.71 \%)$ and miscellaneous samples from swabs, sputum and body fluids were $144(13.35 \%)$. The 86 samples out of 144 miscellaneous samples were swabs from various body sites while 40 were from sputum and only 18 were from cerebrospinal fluids.

\section{Blood samples}

Freshly drawn, 3-5 mL blood was immediately transferred to $50 \mathrm{~mL}$ of Tryptone Soya broth (CM0129-OXOID), and incubated at $37^{\circ} \mathrm{C}$ for 24 hours. 
PREVALENCE OF MULTIDRUG RESISTANT STAPHYLOCOCCUS AUREUS ISOLATES IN CLINICAL SPECIMENS COLLECTED FROM LOCAL PATIENTS OF CHITTAGONG, BANGLADESH

Then sub-cultured on Blood Agar (CM 0055- OXOID), Chocolate agar (by heating Blood Agar at $63^{\circ} \mathrm{C}$ ) and MacConkey Agar (CM 0007-OXOID) plates, and incubated for 24 hours at $37^{\circ} \mathrm{C}$.

\section{Pus samples}

Pus samples were directly inoculated on Blood Agar (CM 0055- OXOID), Chocolate agar (by heating Blood Agar at $63^{\circ} \mathrm{C}$ ) and MacConkey Agar (CM 0007-OXOID) plates, and incubated for 24 hours at $37^{\circ} \mathrm{C}$.

\section{Miscellaneous samples}

Body fluids, sputum and swab samples were cultured on Blood agar, MacConkey agar and Chocolate agar and incubated for 24 to 48 hours at $37^{\circ} \mathrm{C}$. After incubation, the bacterial isolates were randomly selected on the basis of their colony characteristics, sub-cultured and preserved for further studies.

\section{Isolation of organisms from different samples and their preservation}

Cultures of pus, blood and miscellaneous samples on Blood agar, MacConkey agar and Chocolate agar were observed after incubation and discrete and distinct colonies with respect to size, color, shape were picked up and transferred into agar slant. During the study period the cultures were preserved by subculturing periodically to keep the isolates viable and their characteristics unimpaired.

\section{Determination of prevalence of Gram positive cocci}

The isolated organisms were subject to Gram staining to observe their size, shape and arrangement. Presence of Gram positive coccoidal bacteria was also noted to determine their prevalence in the samples from which they were isolated.

\section{Determination of prevalence of Staphylococcus aureus}

Oraganisms showing gram positive characteristics and coccoid shape during Gram staining were further subjected to certain biochemical tests such as hemolysis, catalase, coagulase, DNase and mannitol fermentation tests. The results obtained from these tests were compared with the standard description given in the Bergey's Manual of Determinative Bacteriology (9th edition) for species determination (Holt et al.1994). The number of Staphylococcus aureus positive samples was also counted to evaluate the prevalence of this organism in collected clinical samples. 
KHAN et al.

\section{Determination of antibiogram}

The sensitivity pattern of the isolates against commonly used different groups of antibiotics such as ampicillin, cefradine, gentamicin, ciprofloxacin and vancomycin was determined by disk diffusion method, using National Committee for Clinical Laboratory Standards (NCCLS) criteria to interpret diameter of inhibition zone (Bauer et al.1966). Commercially available disks were applied as recommended on Mueller Hinton Agar (CM0337-OXOID).

\section{Determination of multidrug resistant isolates}

The antibiograms obtained from 38 staphylococcal isolates were scanned for the isolates resistant to two or more of the antibiotics used. The number of Staphylococcus aureus isolates exhibiting multidrug resistance was calculated.

\section{Determination of $M I C$}

Microdilution method was used to determine the minimum inhibitory concentrations (MIC) of antibiotics against Staphylococcus aureus. Serial two fold dilution concentrations of ampicillin, cefradine, gentamicin, ciprofloxacin and vancomycin active pharmaceutical ingredient (API) and their respective brand were made and tested against $S$. aureus from the clinical specimens.

Determination of $M B C$

Once the MIC obtained the MBC was evaluated by microdilution method (NCCLS. 1999).

\section{RESULTS AND DISCUSSION}

\section{Prevalence of Gram-positive cocci}

During the study period, 300 of the 549 pus samples produce bacterial colonies on different agar media. Of these growth positive samples, after Gram staining 116 were found to contain Gram positive cocci. In case of blood samples, 385 samples were screened during the study, out of which 116 exhibited bacterial growth. Presence of gram positive cocci was detected in 33 of these 116 samples. In case of miscellaneous (body fluids/sputum/swabs), a total of 144 samples were received, out of which 62 showed bacterial growth. Among these, 22 were found with the presence of gram-positive cocci (Table-1). The data obtained from the study conducted at Pakistan Institute of Medical Sciences, Islamabad is supportive of the present study, where a large number of Gram-positive cocci were isolated from various blood, pus, urine and miscellaneous samples (Farzana et al. 2005). 
PREVALENCE OF MULTIDRUG RESISTANT STAPHYLOCOCCUS AUREUS ISOLATES IN CLINICAL SPECIMENS COLLECTED FROM LOCAL PATIENTS OF CHITTAGONG, BANGLADESH

TABLE 1: PREVALENCE OF GRAM-POSITIVE COCCI IN VARIOUS CLINICAL SAMPLES

\begin{tabular}{cccccc}
\hline $\begin{array}{c}\text { Name of the } \\
\text { Sample }\end{array}$ & $\begin{array}{c}\text { No. of } \\
\text { sample }\end{array}$ & $\begin{array}{c}\text { No. of } \\
\text { growth } \\
\text { positive } \\
\text { sample }\end{array}$ & $\begin{array}{c}\text { No. of } \\
\text { samples with } \\
\text { Gram positive } \\
\text { cocci }\end{array}$ & $\begin{array}{c}\text { \% of Gram } \\
\text { positive cocci } \\
\text { with respect to } \\
\text { growth positive } \\
\text { sample }\end{array}$ & $\begin{array}{c}\text { \% of Gram } \\
\text { positive cocci } \\
\text { with respect to } \\
\text { total sample }\end{array}$ \\
\hline Pus & 549 & 300 & 116 & $38.67 \%$ & $21.13 \%$ \\
Blood & 385 & 116 & 33 & $28.45 \%$ & $8.57 \%$ \\
$\begin{array}{c}\text { Miscellane } \\
\text { ous (swab, } \\
\text { sputum \& } \\
\text { body fluid) }\end{array}$ & 144 & 62 & 22 & $35.48 \%$ & $15.28 \%$ \\
\hline
\end{tabular}

Prevalence of Staphylococcus aureus

After performing the biochemical tests, all coagulase positive isolates were identified as Staphylococcus aureus when the results compared with the standard description given in Bergey's Manual of Determinative Bacteriology (9th edition) (Holt et al.1994).Out of the 116 Gram-positive cocci collected from pus samples during the study periods, 30 were recognized as Staphylococcus aureus. The number of Gram-positive cocci isolated from blood was 33 of which only 4 were found as Staphylococcus aureus. Same number of Staphylococcus aureus isolates were detected among the 22 Gram-positive cocci isolated from the Miscellaneous (swab, sputum \& body fluid) samples (Table-2).

Studies analogous to the present one conducted in Norwegian and Portuguese pediatric hospitals for three years on hospital acquired infection and found high prevalence of Staphylococcus aureus in clinical specimens of blood, pus, urine and in various miscellaneous samples (Anderson et al.2000 and Sa Leao et al.1999). 
KHAN et al.

TABLE 2: PREVALENCE OF STAPHYLOCOCCUS AUREUS IN VARIOUS CLINICAL SAMPLES

\begin{tabular}{cccccc}
\hline $\begin{array}{c}\text { Name of the } \\
\text { Sample }\end{array}$ & $\begin{array}{c}\text { No. of } \\
\text { samples }\end{array}$ & $\begin{array}{c}\text { No. of } \\
\text { samples with } \\
\text { Gram } \\
\text { positive } \\
\text { cocci }\end{array}$ & $\begin{array}{c}\text { No. of Gram } \\
\text { positive cocci } \\
\text { producing } \\
\text { coagulase }\end{array}$ & $\begin{array}{c}\% \text { of } \\
\text { Staphylococcus } \\
\text { aureus } \text { with } \\
\text { respect to total } \\
\text { Gram positive } \\
\text { cocci }\end{array}$ & $\begin{array}{c}\text { Staphylococcus } \\
\text { aureus } \text { with } \\
\text { respect to total } \\
\text { sample }\end{array}$ \\
\hline Pus & 549 & 116 & 30 & $25.86 \%$ & $5.46 \%$ \\
$\begin{array}{c}\text { Blood } \\
\text { Miscellaneous } \\
\text { (swab, } \\
\text { sputum \& } \\
\text { body fluid) }\end{array}$ & 385 & 33 & 4 & $12.12 \%$ & $1.04 \%$ \\
\hline
\end{tabular}

Susceptibility Pattern of S. aureus

The susceptibility of 38 isolates of Staphylococcus aureus were assessed against various antimicrobial agents by disk diffusion method (Bauer et al.1966). Most of the S. aureus were drug resistant and vancomycin was emerged as the most effective drug against these clinical isolates. There was no resistant isolate against vancomycin and only $4(10.52 \%)$ isolates had intermediate sensitivity. Gentamicin was the second most effective drug against these isolates, with 41.94\% sensitive strains. Ciprofloxacin and cefradine were found to be effective antimicrobial drug against these S. aureus exhibiting $38.06 \%$ and $32.27 \%$ sensitivity, respectively, whereas ampicillin demonstrated only $5.26 \%$ sensitivity (Table-3).

In the present study it is found that the increase in antibiotic resistance among the $S$. aureus isolates is alarming and many antibiotics which were once thought to be the first choice in the treatment of Gram-positive cocci are now obsolete. Although cephalosporins are now largely being prescribed for the treatment of both gram-positive and gram-negative bacteria for their less side effects \& pharmacology, it has been seen that these drugs are now becoming more insensitive. Ampicillins showed the highest percentage of antibiotic resistance. It has also been seen from the present study that the glycopeptide vancomycin has been the only effective drug in the treatment of $S$. aureus infection. Farzana et al. 
PREVALENCE OF MULTIDRUG RESISTANT STAPHYLOCOCCUS AUREUS ISOLATES IN CLINICAL SPECIMENS COLLECTED FROM LOCAL PATIENTS OF CHITTAGONG, BANGLADESH

2005 and Siddiqui et al. 2002, both reported almost similar antibiotic sensitivity pattern of Staphylococcus aureus which were isolated from pus and wound swabs. They also reported more than $20 \%$ isolates from blood which were resistant to ampicillin, cefradine and gentamicin.

TABLE 3: EFFICACY OF FIVE MAJOR GROUPS OF ANTIBIOTICS AGAINST $S$. AUREUS ISOLATES

\begin{tabular}{cccc}
\hline Antibiotics used & $\begin{array}{c}\text { No. of sensitive } \\
\text { isolates }\end{array}$ & $\begin{array}{c}\text { No. of intermediate } \\
\text { isolates }\end{array}$ & $\begin{array}{c}\text { No. of resistant } \\
\text { isolates }\end{array}$ \\
\hline Ampicillin & $2(5.26 \%)$ & $1(2.63 \%)$ & $35(92.1 \%)$ \\
Cefradine & $12(32.26 \%)$ & $3(7.74 \%)$ & $23(60 \%)$ \\
Gentamicin & $16(41.9 \%)$ & 0 & $22(58.1 \%)$ \\
Ciprofloxacin & $14(38 \%)$ & $1(2.6 \%)$ & $23(59.35 \%)$ \\
Vancomycin & $24(61.9 \%)$ & $14(38 \%)$ & 0 \\
\hline
\end{tabular}

Multidrug resistant Staphylococcus aureus isolates

Among 30 isolates of $S$. aureus from pus multi drug resistant (MDR) isolates were 21 in number. While among the 4 S. aureus isolates from blood, 2 were multi drug resistant and out of $4 \mathrm{~S}$. aureus isolates from miscellaneous samples, 3 were multi drug resistant (Table-4). High rates of resistance with penicillin, aminoglycoside monotherapy and toward fluoroquinolones was observed in the work of Fish et al.1995. Raquel et al. 1999, DeLancaster et al. 2000 and Gales et al. 2000 have also reported multidrug resistant S. aureus as a cause of nosocomial infection. 
KHAN et al.

TABLE 4: MULTIDRUG RESISTANCE AMONG THE CLINICAL ISOLATES OF S. AUREUS

\begin{tabular}{cccc}
\hline $\begin{array}{c}\text { Name of the } \\
\text { Sample }\end{array}$ & $\begin{array}{c}\text { No. of } S . \\
\text { aureus } \\
\text { isolates }\end{array}$ & $\begin{array}{c}\text { No. of multidrug resistant } \\
\text { S. aureus isolates }\end{array}$ & $\begin{array}{c}\text { Percentage of multidrug } \\
\text { resistant S. aureus isolates }\end{array}$ \\
\hline Pus & 30 & 21 & $70 \%$ \\
$\begin{array}{c}\text { Blood } \\
\text { Miscellaneous } \\
\text { (swab, }\end{array}$ & 4 & 2 & $50 \%$ \\
$\begin{array}{c}\text { sputum \& } \\
\text { body fluid) }\end{array}$ & 4 & 3 & $75 \%$ \\
\hline
\end{tabular}

MIC \& MBC of five groups of antibiotics against clinical isolates of Staphylococcus aureus

MIC and MBC of five groups of antibiotics, namely ampicillin, cefradine, gentamicin, ciprofloxacin and vancomycin were determined for all the $38 \mathrm{~S}$. aureus isolates (Table 5). From the MIC of vancomycin, it was noted that most of the isolates were inhibited at a concentration range between $1 \mu \mathrm{g} / \mathrm{mL}$ and 8 $\mu \mathrm{g} / \mathrm{mL}$. The MBC of vancomycin was within the range of $4 \mu \mathrm{g} / \mathrm{mL}$ to $16 \mu \mathrm{g} / \mathrm{mL}$ which was 1 to 2 times higher than the MIC value. These finding are in line with the findings of Visser et al. 1991 and Zaoutis et al.1999, who reported that MIC and $\mathrm{MBC}$ could not be assumed to be in the same range and the $\mathrm{MBC}$ almost always within the two folds of the MIC.

TABLE-5: MIC AND MBC OF FIVE TESTED GROUPS OF ANTIBIOTICS AGAINST THE CLINICAL ISOLATES OF S. AUREUS

\begin{tabular}{ccc}
\hline Antibiotics used & MIC & MBC \\
\hline Penicillin & 8 to $2048 \mu \mathrm{g} / \mathrm{mL}$ & $32 \mu \mathrm{g} / \mathrm{mL}$ to $>1024 \mu \mathrm{g} / \mathrm{mL}$ \\
Cephalosporin & 8 to $2048 \mu \mathrm{g} / \mathrm{mL}$ & $32 \mu \mathrm{g} / \mathrm{mL}$ to $>1024 \mu \mathrm{g} / \mathrm{mL}$ \\
Aminoglycosides & 4 to $2048 \mu \mathrm{g} / \mathrm{mL}$ & $16 \mu \mathrm{g} / \mathrm{mL}$ to $>1024 \mu \mathrm{g} / \mathrm{mL}$ \\
Quinolones & $1 \mu \mathrm{g} / \mathrm{mL}$ to $128 \mu \mathrm{g} / \mathrm{mL}$ & $4 \mu \mathrm{g} / \mathrm{mL}$ to $1024 \mu \mathrm{g} / \mathrm{mL}$ \\
Vancomycin & $2 \mu \mathrm{g} / \mathrm{mL}$ to $8 \mu \mathrm{g} / \mathrm{mL}$ & $4 \mu \mathrm{g} / \mathrm{mL}$ to $16 \mu \mathrm{g} / \mathrm{mL}$ \\
& &
\end{tabular}


PREVALENCE OF MULTIDRUG RESISTANT STAPHYLOCOCCUS AUREUS ISOLATES IN CLINICAL SPECIMENS COLLECTED FROM LOCAL PATIENTS OF CHITTAGONG, BANGLADESH

\section{REFERENCES}

ANDERSEN, B. M., RINGERTZ, S. H., GULLORD, T. P., HERMANSEN, W., LELEK, M., NORMAN, B. I., NYSTAN, M. T., ANDERSON, K., ROED, R. TH., SMIDSANG, I. J., SOLHEIM, N., TANDBERG, S., HALSNES, R. AND HOYSTAD, M. W. 2000. A three year survey of nosocomial and community acquired infections, antibiotic treatment and re-hospitalization in a Norwegian health region. J. Hosp. Infect. 44:214:223.

BAUER, A. W., KIRBY, W. M., SHERRIS, J. C. AND TURCK, M. 1966. Antibiotic susceptibility testing by standardized single disk method. Am. J. Clin. Pathol. 45:493-496

DELANCASTRE, H., SANTOS, I., SANCHES, I. S. AND TOMASZ, A. 2000. Streptococcus pneumoniae: Molecular Biology and Mechanisms of Disease., Clinical Microbiology and Molecular Microbiology in alliance CEM/NET. Mary Ann Liebert, Inc., Larchmont, New York, U.S.A. Pp.451-456

FARZANA, K., SATTAR, S. A. AND HAMEED, A. 2005. Resistance pattern of antibiotics against clinical isolates of Staphylococcus aureus. Pak J Pharm Sci. 18(4):18-22.

FISH, D. N., PISCITELLI, S. C. AND DANZIGER, L. H. 1995. Development of resistance during antimicrobial therapy: A review of antibiotic classes and patient characteristics in 173 studies. Pharmacotherapy. 15: 279-291.

FOSTER, T. J. AND MCDEVITT, D. 1994. Surface associated proteins of Staphylococcus aureus: their possible role in virulence, FEMS Microbiol. Lett. 118: 199-205.

GALES, A. C., JONES, R. N., PFALLER, M. A., GORDON, K. A., SADER, H. S., SAMPAIO, J., ZOCCOLI, C., CASELLAS, J. M., SMAYVESKY, J., PALAVECINO, E., PRADO, V., ROBELDO, J. A., SIFUENTESOSORNIO, M. J., GUZMAN-BLANCO, M. AND BAGNULO, H. 2000. Two year assessment of pathogen frequency and antimicrobial resistance pattern among organisms isolated from skin and soft tissue infection in Latin American hospitals: results from the SENTRY antimicrobial surveillance program, 1997-1998. Int. J. Infect. Dis., 4: 7-84. 
HOLT, J. G., KRIEG, N. R., SNEATH, P. H. A., STALY, J. T. AND WILLIAMS, S. T. 1994. Bergey's Manual of Determinative Bacteriology, 9th ed. Lippicott Williams and Wilkins Co. Baltimore. pp.532, 544-545.

LOWY, F. D. 1998. Staphylococcus aureus infections. New Eng. J. Med. 339:520-532.

MAHMOOD, A., RAFIQUE, S., QAYYUM, M. AND QAZILBASH, A.A. 2001. Prevalence of nosocomial and community based MRSA. Pak. J. Med. Res. 40: 86-89.

NCCLS (National Committee for Clinical Laboratory Standards). 1999. Methods for determining bactericidal activity of antimicrobial agents. Approved guideline M26-A, NCCLS, Wayne, Pa. 8-14 pp

NCCLS (National Committee for Clinical Laboratory Standards). 1993. Performance standards for antimicrobial disk susceptibility tests. $5^{\text {th }}$ ed..Approved standard M2-A5.NCCLS, Villanova, and Pa. 8-14 pp.

POLK, R. 1999. Optimal use of modern antibiotics: Emerging trends. Clin. Infect. Dis. 29: 264-274.

RAQUEL, S. L, SANCHES, I. S., DIAS, D., PERES, I., BARROS, R. M. AND DELANCASTRE, H. 1999. Detection of an Archaic Clone of Staphylococcus aureus with Low-Level Resistance to Methicillin in a Pediatric Hospital in Portugal and in International Samples: Relics of a Formerly Widely Disseminated Strain? Journal of Clinical Microbiology, 37 (6): 1913-1920

SA-LEAO, R., SANTOS S. I., DIAS, D., PERES, I., BARROS, R. M. AND DE LANCASTRE, H. 1999. Detection of an archaic clone of Staphylococcus aureus with low-level resistance to methicillin in a pediatric hospital in Portugal and in international samples: relics of a formerly widely disseminated strain. J. Clin. Microbiol. 37(6): 1913-20.

SIDDIQUI, F., BINT-E-MASOOD, M., NOOR-US-SABA, SAMAD, A., QAYYUM, M. AND QAZILBASH, A. A. 2002. Antibiogram sensitivity pattern of MRSA isolates from pus samples. Pak. J. Biol Sci. 5: 491-493.

TODAR, K. 2008. University of Wisconsin Madison. Dept. of Bact. Staphylococcus. www.bact.wise.edu/Bact. 330/ lecture staph. 29 Nov. 2008. 
PREVALENCE OF MULTIDRUG RESISTANT STAPHYLOCOCCUS AUREUS ISOLATES IN CLINICAL SPECIMENS COLLECTED FROM LOCAL PATIENTS OF CHITTAGONG, BANGLADESH

VISSER, M. R., ROZENBER-ARSKA, M., BEUMER, H., HOEPELMAN, I. M. AND VERHOEF, J. 1991. Comparative in-vitro Antibacterial activity of sparfloxacin, AT-4140; RP 642006 a new quinolones. Antimicrob. Agents Chemother. 35:858-868.

ZAOUTIS, T., SCHNEIDER, B., MOORE, L. S. AND KLEIN, J. D. 1999. Antibiotic susceptibilities of group $\mathrm{C}$ and group $\mathrm{G}$ streptococci isolated from patients with invasive infections: Evidence of vancomycin tolerance among group G serotypes J. Clin. Microbiol. 37:3380-3383.

Manuscript received on 03.05.2012; Accepted on 07.07.2012

The Chittagong University Journal of Biological Sciences, Vol. 6 (1 \& 2). Page No. 